\title{
Geology and geochemistry of palaeoproterozoic low-grade metabasic volcanic rocks from Salumber area, Aravalli Supergroup, NW India
}

\author{
L S SheKhaWAT ${ }^{1}$, M K PANDiT ${ }^{2, *}$ and D W Joshi ${ }^{1}$ \\ ${ }^{1}$ Geological Survey of India, Jhalana Dungari, Jaipur 302004 , India. \\ ${ }^{2}$ Department of Geology, University of Rajasthan, Jaipur 302 004, India. \\ *e-mail: mpandit_jp1@sancharnet.in
}

The Palaeoproterozoic Aravalli Supergroup in Salumber region includes a basal unit of metabasic volcanic rocks (Salumber volcanic rocks) overlain by a volcaniclastic/conglomerate one. Although these volcanic rocks have been metamorphosed to green-schist facies, some primary volcanic features are still preserved. This metabasic volcanic sequence can be further differentiated on the basis of textural variations, and the mineral assemblages are: (a) oligoclase + actinolite + chlorite + epidote; and (b) oligoclase + hornblende + chlorite + biotite $+\mathrm{Fe}-\mathrm{Ti}$ oxides. The $\mathrm{SiO}_{2}$ content ranges from $\sim 47.7$ to $55.8 \%$ and $\mathrm{MgO}$ from $\sim 4.2$ to $12.8 \%$. Geochemical characteristics allow their subdivision into high $\mathrm{Mg}$ and Fe tholeiites. Inverse relationship of $\mathrm{MgO}$ with silica, alkalis and $\mathrm{Zr}$ is generally consistent with fractionation mechanism, also suggested by a change in colour of the rocks from dark greenish to light greenish towards the upper parts of the sequence. These metabasic volcanic rocks are enriched in incompatible trace elements and LREE ( $\mathrm{La}=30-40 \times$ chondrite, $\mathrm{Lu}=2-5 \times$ chondrite), and demonstrate affinity mainly with MORB and within plate settings in geochemical tectonic discrimination schemes. The geochemical characteristics suggest a complex evolutionary history envisaging derivation of the melt from an enriched heterogeneous lithospheric source.

\section{Introduction}

The Palaeoproterozoic has been the most dynamic period in the Earth's history as it heralded a new major stage of continental fragmentation and worldwide intrusion of mafic dykes and sills between 2.4 and $2 \mathrm{Ga}$ (Windley 1999). Extension of the continental lithosphere has often been associated with basic magmatism, the latter usually a suitable candidate for studying implications on the basin development and its evolution as well as in modeling the subcontinental mantle source (Hawkesworth et al 1990; Sweeny et al 1994; Camire et al 1995). Basic volcanic rocks (subsequently metamorphosed) are present in the basal part of the Palaeoproterozoic Aravalli Supergroup in NW India. These volcanic rocks were initially thought to be $\sim 2500$ Ma (Sarkar 1980; Sastry et al 1984) on the basis of the geochronologic data on the basement Berach granite. The $\mathrm{Sm}-\mathrm{Nd}$ radiometric data (Macdougall et al 1984) on these volcanic rocks failed to yield a valid isochron. Recently, a $2150 \mathrm{Ma} \mathrm{Pb}-\mathrm{Pb}$ age for the galena associated with the basal Aravalli volcanic rocks has been reported (see Roy and Jakhar 2002). Prevailing models on tectonic evolution of the Aravalli basin include:

- a stable shelf along the gneissic cratonic mass of the Archaean basement (Banerjee 1971);

- an intra-cratonic epicontinental sea (Roy and Paliwal 1981);

- large-scale ensialic orogenesis (Sharma 1988); and

Keywords. Palaeoproterozoic; metabasic volcanic rocks; Aravalli Supergroup; Salumber; NW India. 

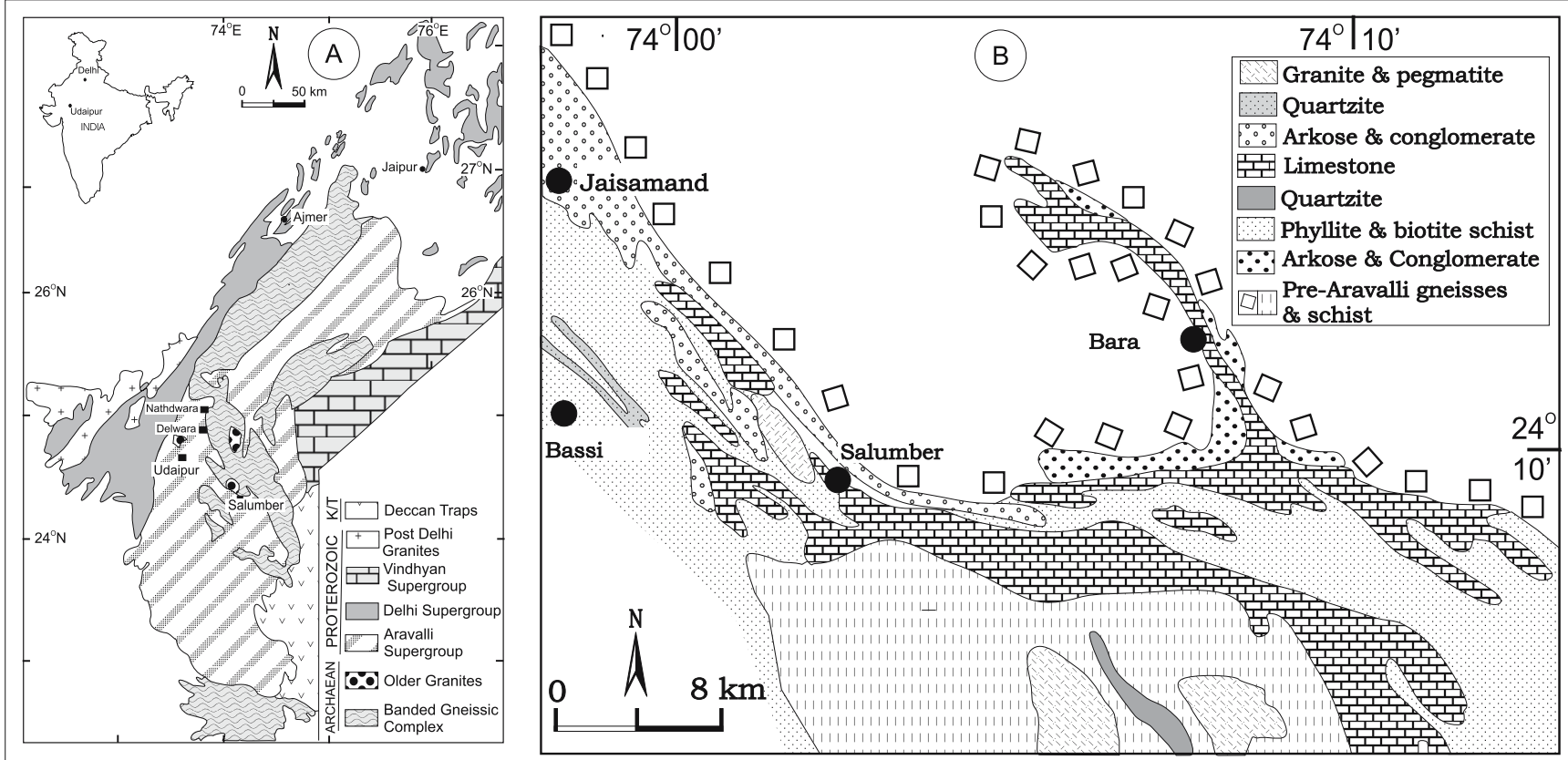

Figure 1. (A) Simplified geological map of Aravalli Mountain Region (NW India) showing disposition of major stratigraphic units and location of Salumber (adapted from Heron 1953; Gupta et al 1997 and other published maps (e.g., Roy and Jakhar 2002). (B) Regional geological map of Salumber-Bara area (adapted from Heron 1953) mainly comprising Aravalli gneisses and schists developed over an Archaean basement (BGC - Banded Gneissic Complex).

- a complex series of grabens (Roy 1988) or rift basins linked at triple junctions with one or more failed arms in a typically ensialic setting (Roy et al 1993).

Sinha Roy (1988) proposed the development of Aravalli Supergroup (figure 1) through a sequence of rifting, generation of oceanic crust and its consumption (Wilson Cycle). A number of metabasic dykes, correlative with Aravalli metabasalts (Roy and Kröner 1996), are present within the basement (Shekhawat et al 2000, 2001). It has been established that continental rifting is often manifested in intrusion of mafic dykes/sills, alkaline complexes and flood basalt volcanism (Windley 1999). Geochemical studies on the basal Aravalli volcanic rocks have been mainly confined to the northern segment (Nathdwara-Delwara area) of the Aravalli Supergroup (Ahmad and Rajamani 1991; Ahmad and Tarney 1994) and little attention has been given to the metabasic volcanic rocks in the southern segment where they occur as a key horizon in the basal part (figure 2).

This paper describes geological setting, geochemistry and petrogenetic aspects of Salumber volcanic rocks (figure 2). The stratigraphic status of the contentious volcaniclastic/conglomerate unit has also been discussed in the light of the geological mapping carried out.

\section{Geological setting}

The Aravalli supracrustals overlie Archaean granitoids (Banded Gneissic Complex - BGC of Heron 1953) in the northwestern Indian shield (figure 1). The basement-Aravalli Supergroup contact is sheared at many places; however, in the northern portion of the study area and in other parts, intrusion of granite along the Aravalli-basement interface has been observed (figure 2; Shekhawat et al 2001). According to Bose et al (1996) the intrusive granites may possibly be a product of remobilization of the basement in response to the deformation of the supracrustal rocks. These authors have also opined that the younger granite has intruded and assimilated the basal Aravalli lithounits that can be seen as 'enclaves' of basal metavolcanic rocks within granites. This contention is in agreement with the observation that the Archaean crust locally adjacent to the margins of Proterozoic orogenic belts forms the source material for magma generation (Emslee 1991). It is interesting to note that the basement rocks occurring near Boraj, Ghaghri and Bedawal do not show any evidence of post-crystallization deformation except the development of shears (cf. Roy 1988). The basement granitoids contain metabasic dykes, emplaced along these shears. The shears are represented by mylonites, phyllonites and a zone of silcification. Extensive silicification, observed along the shears at some places, has resulted in development of 


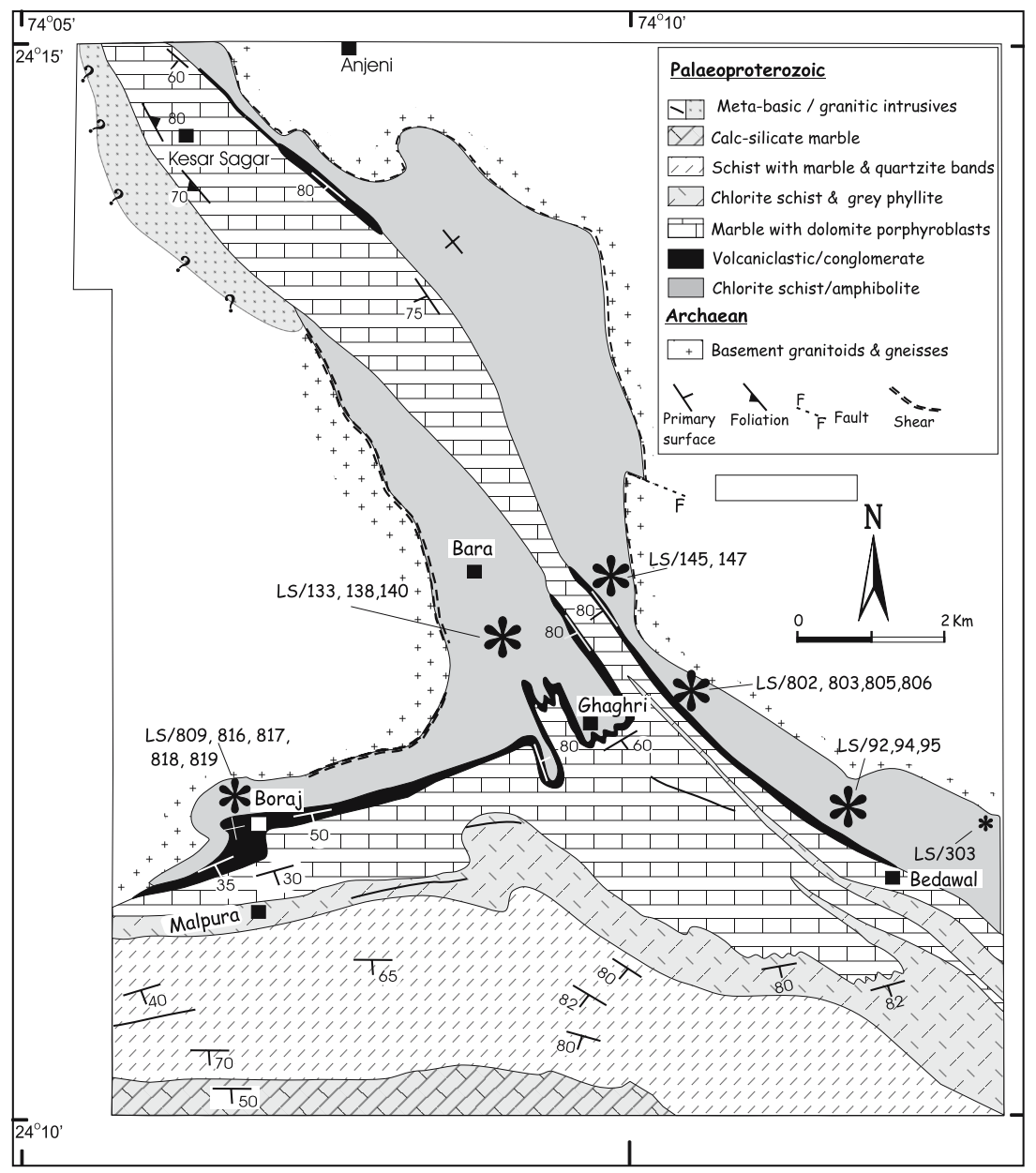

Figure 2. Geological map of the study area. Sampled sections are indicated by an asterisk mark and sample numbers are also provided.

quartz reefs. The shears trend parallel to basin margin of the Aravalli basin and follow a NNWSSE trend in the vicinity of Bara and Kesar Sagar whereas WNW-ESE trending shears are present to the north of Salumber (see also Bose et al 1996). Most of the shears have steep dips; however, some shallow dipping ones have also been noted to the west of Boraj $\left(24^{\circ} 08^{\prime} 55^{\prime \prime} \mathrm{N}, 74^{\circ} 05^{\prime} 08^{\prime \prime} \mathrm{E}\right)$. The chilled contact of metabasic dykes with the host rocks is still preserved despite greenschist facies metamorphism. Enclaves of metabasic rocks predating the shears, therefore older than those along the shears, have also been observed in the Boraj area.

Aravalli Supergroup in Salumber area has been divided into an older Salumber Group and a younger Jaisamand Group (Shekhawat et al 2001); only the lower part of the Salumber Group is developed in the study area. The Salumber Group is represented by a lower Bedawal Formation and an upper Malpura Formation. A volcaniclastic/conglomerate unit marks a contact between the two. Shekhawat et al (2001) have correlated the Bedawal Formation with Delwara Formation of Roy et al (1988) and with metabasalt of Delwara Group of Sinha Roy et al (1998).

\subsection{Bedawal Formation}

The Bedawal Formation comprises Salumber volcanic rocks which form a sequence of amygdulebearing metabasic volcanic rocks (now metamorphosed to chlorite schist and amphibolite) in Bedawal-Ghaghri and Bara areas. The amygdules are made of quartz, carbonate and epidote and are variably deformed. However, in low strain zones the amygdules have near spherical geometry. There is a general decrease in the abundance of mafic minerals (mainly hornblende and chlorite) from lower to upper part of the sequence which is also reflected in a gradual change in colour of the rock from dark green to light green. The basal part of the sequence in Bedawal and Bara sections also shows development of actinolite needles from few $\mathrm{mm}$ to $3 \mathrm{~cm}$ long. The metabasic volcanic rocks in the middle part of the sequence show oval to circular segregates of mafic minerals $(0.2$ to $0.5 \mathrm{~cm})$, mainly 
biotite and chlorite imparting a spotted appearance to the rock. This spotted metabasic volcanic lithounit is the most predominant unit and traceable within the metabasic volcanic sequence. The spotted metabasic volcanic rocks have also been described from the Nathdwara area (Ahmad and Rajamani 1991). The upper part of the metabasic volcanic sequence shows still-preserved glomeroporphyritic texture with well-preserved plagioclase phenocrysts varying in size from 2 to $20 \mathrm{~mm}$. Some aphyric metabasic volcanic lithounits have also been noticed. However, near the northern end of the study area, only the spotted metabasic volcanic lithounit is present on either side of the volcaniclastic/conglomerate unit. The metabasic volcanic sequence is present on the eastern as well as western basin margins in Ghaghri-Bara area (figure 2). Further NNW, in the Kesar Sagar area, the metabasic volcanic rocks are present only on the eastern basin margin.

\subsection{Malpura Formation}

\subsubsection{Volcaniclastic/conglomerate unit}

The Malpura Formation begins with a volcaniclastic/conglomerate unit marking an unconformity with the underlying Bedawal Formation. The unconformable relationship is not clear in areas where volcaniclastic/conglomerate unit is absent because both the underlying and overlying formations show similar attitude. The volcaniclastic/conglomerate unit is present on either side of the central portion of the Aravalli basin in the Ghaghri area. The volcaniclastic character of this unit is attributed to the presence of clasts derived from the underlying metabasic volcanic sequence. Some volcanic bomb like structure has also been noticed from this unit. The unit is composed of highly unsorted clasts (mainly pebbles and cobbles) derived from the underlying metabasic volcanic sequence, quartzite, pebbly quartzite, vein quartz, ferruginous quartzite and granite. The clast size varies from a few $\mathrm{mm}$ across to more than $30 \mathrm{~cm}$. This unit shows a variation from clast supported type to matrix supported type along the strike. In the Boraj area, the predominant clasts have been derived from the underlying metabasic volcanic rocks and from quartzite. A few leucogranite clasts are also present. The quartzite clasts are subrounded to well-rounded. The matrix is represented mainly by an actinolite-biotite-chlorite assemblage, although quartzo-feldspathic matrix has also been reported (Ray et al 1988). In the northern part of study area, all the clasts have been derived from the metabasic volcanic rocks only where the highly unsorted clasts from all the textural variants of the metabasic volcanic sequence including porphyritic and spotted lithounits are present. Here the clasts are seen embedded in a chloritic matrix. Current bedding is also present in some relatively clast-free portions of the lithounit with an arkosic matrix. The current bedding indicates younging towards centre of the basin.

Stratigraphic status of the volcaniclastic/ conglomerate unit is equivocal. Gupta (1934) described the unit as a conglomerate occupying the core of an anticline; Sengupta (1976) also considered the conglomerate to be the basal unit of Aravalli sequence. Gupta et al (1997) described the western band of the unit in Ghaghri area as epiclastic volcanic conglomerate whereas the eastern band was considered as quartzite, stratigraphically younger than the western one. In contradiction to the above-cited views, strike mapping revealed that the volcaniclastic/conglomerate unit overlies Salumber volcanic rocks of the Bedawal Formation (Shekhawat 1998).

\subsubsection{Marble unit}

The marble unit overlies the volcaniclastic/ conglomerate one where the latter is present. The marble is medium-to-coarse grained and contains pink and gray porphyroblasts of dolomite which vary from a few $\mathrm{mm}$ to $2 \mathrm{~cm}$ across. The marble unit also contains some schist and quartzite bands, and occasional basic and quartzite clasts. In the Kesar Sagar area, the marble unit along the western part of the basin is seen in contact with granite while in Bara area, the marble occupies the central portion. The marble is composed mainly of crystalline carbonates $(\sim 75 \%)$ with minor quartz and actinolite. Plagioclase is present as inclusions within dolomitic porphyroblasts.

\subsubsection{Chlorite-schist unit}

The marble unit is overlain by chlorite schist unit, present in Bedawal, Ghaghri and Malpura areas. Occasional interbands of gray schist are also noticed within the chlorite schist unit. In the north, the chlorite schist unit extends up to Ghaghri only (figure 2).

\section{Geochemistry of Salumber metabasic volcanic rocks}

\subsection{Analytical procedure and sample selection}

Representative metabasic volcanic rock samples were selected and apparently fresh or least altered samples were picked to minimize alteration effects. In most cases, the basal portions of flow sequences are highly sheared and did not 
yield suitable samples. Therefore, the samples from basal portions of the metabasic volcanic sequence were not considered for geochemical study, because they show significant mineralogical reconstitution (development of actinolite needles) during metamorphism. The samples were initially crushed to grit size and amygdule-bearing portions were discarded by careful hand picking before grinding them to -200 mesh size. Major and trace element analyses were carried out on pressed pellets and fused beads by X-ray fluorescence spectroscopy at the Department of Geology, University of Oslo. Rare earth element analyses were carried out by ICP-MS at Wadia Institute of Himalayan Geology, Dehradun. The major and trace element abundances are listed in table 1 and REE data in table 2. Reported precision varies from 5 to $7 \%$ for major and trace elements and up to $10 \%$ for REE. The samples are listed section-wise and their $\mathrm{MgO}$ content corresponds to their stratigraphic position. Those with higher $\mathrm{MgO}$ content are older in the metabasic volcanic sequence.

The metabasic volcanic rocks are fine- to medium-grained and schistose to massive. Hornblende is the most abundant mineral; however, development of chlorite in schistose types is also seen. Actinolite porphyroblasts are also common in the lower part of the sequence. Actinolite has formed by uralitization of pre-existing pyroxene with simultaneous breakdown of Ca-plagioclase into more sodic variety (see also Goel 1988). Aggregates of biotite crystals in the middle part of the sequence have imparted a spotted appearance to the rock. Sericitized plagioclase (oligoclase) occurs mainly in the groundmass, however, in the upper part of the sequence large crystals of oligoclase depicting relict glomeroporphyritic texture are also present. Oligoclase shows well-developed twinning and compositional zoning, which probably represents a relict magmatic feature. Uralitized pyroxene along with epidote is also seen in some thin sections. Opaque minerals (mainly magnetite and rutile) occur both as euhedral to subhedral crystals and in sieve-textured diffused form.

\subsection{Alteration effects}

Post-depositional processes as well as low- to medium-grade metamorphism are known to affect the mobility of certain elements. Further, some of the analyzed samples in the present study have Loss on Ignition (LOI) values higher than expected (table 1 ). The data were, therefore, plotted in the $\mathrm{CaO} / \mathrm{Al}_{2} \mathrm{O}_{3}-\mathrm{MgO}-\mathrm{SiO}_{2}$ diagram, proposed by Schweitzer and Kröner (1985) to test alteration effects in basalts. As seen, majority of the samples plot in the field of "unaltered basalts' except sample numbers LS/145, LS/147 and LS/303 (figure 3; table 1), these three samples have been discarded in further discussion. Although there is no universally accepted single criterion for evaluating pristine geochemical signatures of primary magmas, certain parameters in combination have been suggested. The $\mathrm{Mg}$ number $>64$ (Green 1971), $\mathrm{FeO}^{\mathrm{t}} / \mathrm{MgO}<1$ (Tatsumi et al 1983), $\mathrm{Ni}=>235 \mathrm{ppm}$ (Sato 1977), $\mathrm{MgO}>6 \%$ (Luhr 1997) and $\mathrm{SiO}_{2}$ content < 52\% (Verma 2003) are some of such criteria. In the present case, it is difficult to evaluate samples on the basis of the above criteria, due to a large variation in elemental abundances. There is a general agreement for basaltic rocks that the REE, HFSE ( $\mathrm{Ti}, \mathrm{Zr}, \mathrm{Y}, \mathrm{Nb}$, Hf, P, Th), transition metals (Sc, V, Cr) and Ndisotopes remain essentially unchanged or immobile during all but most severe hydrothermal alterations (Pearce 1984; Camire et al 1995; Swinden et al 1990). Elements like $\mathrm{Si}, \mathrm{Na}, \mathrm{K}, \mathrm{Sr}, \mathrm{Rb}, \mathrm{Ba}, \mathrm{U}$ are susceptible to modification, being mobile even under low-grade metamorphic conditions (Schiano et al 1993). We have mainly considered relatively immobile elements for petrogenetic modeling as the abundances of $\mathrm{Si}, \mathrm{Na}, \mathrm{K}, \mathrm{Sr}$, etc. might be unreliable on account of their high mobility. The major element data have, however, been plotted for classification and for general characteristics.

\subsection{Major and trace element geochemistry}

The Salumber metavolcanic rocks show a wide variation in $\mathrm{SiO}_{2}$ (47.69 to $55.76 \%$ ) and $\mathrm{MgO}$ (4.17 to $12.83 \%$ ) contents. The $\mathrm{Fe}_{2} \mathrm{O}_{3} *$ abundance varies from 10.86 to $15.26 \%$ (except one sample with $18.65 \%$ ) while $\mathrm{CaO}$ shows a somewhat wider range, from 4.49 to $10.32 \%$. In the $\mathrm{SiO}_{2}-\mathrm{Zr} / \mathrm{TiO}_{2}$ classification scheme, most of the samples plot in a field overlapping between subalkaline basalt and andesite (figure 4). The 'andesite' nomenclature is not supported by the mineralogy and other geochemical parameters and therefore only an expression of higher silica abundance. In view of the mineralogical features (uralitized pyroxene, epidote), high silica in some samples does not seem a primary feature of the magma and can be related to silica mobility. Similar silica levels in basal volcanic rocks have also been reported from other parts of the Aravalli Supergroup (Ahmad and Rajamani 1991). In the Jensen's (1976) cationic discrimination scheme the samples can be further discriminated into tholeiite (both high iron and high magnesian types) and komatiitic basalt. These metabasic volcanic rocks also define an ironenrichment trend and tholeiitic affinity as seen in the AFM diagram (figure 5). In the $\mathrm{Y}+\mathrm{Zr}-\mathrm{TiO}_{2}-$ Cr diagram (Davies et al 1979) these rocks plot between tholeiitic and calc-alkaline trends, however a majority of the high $\mathrm{MgO}$ samples plot along or 


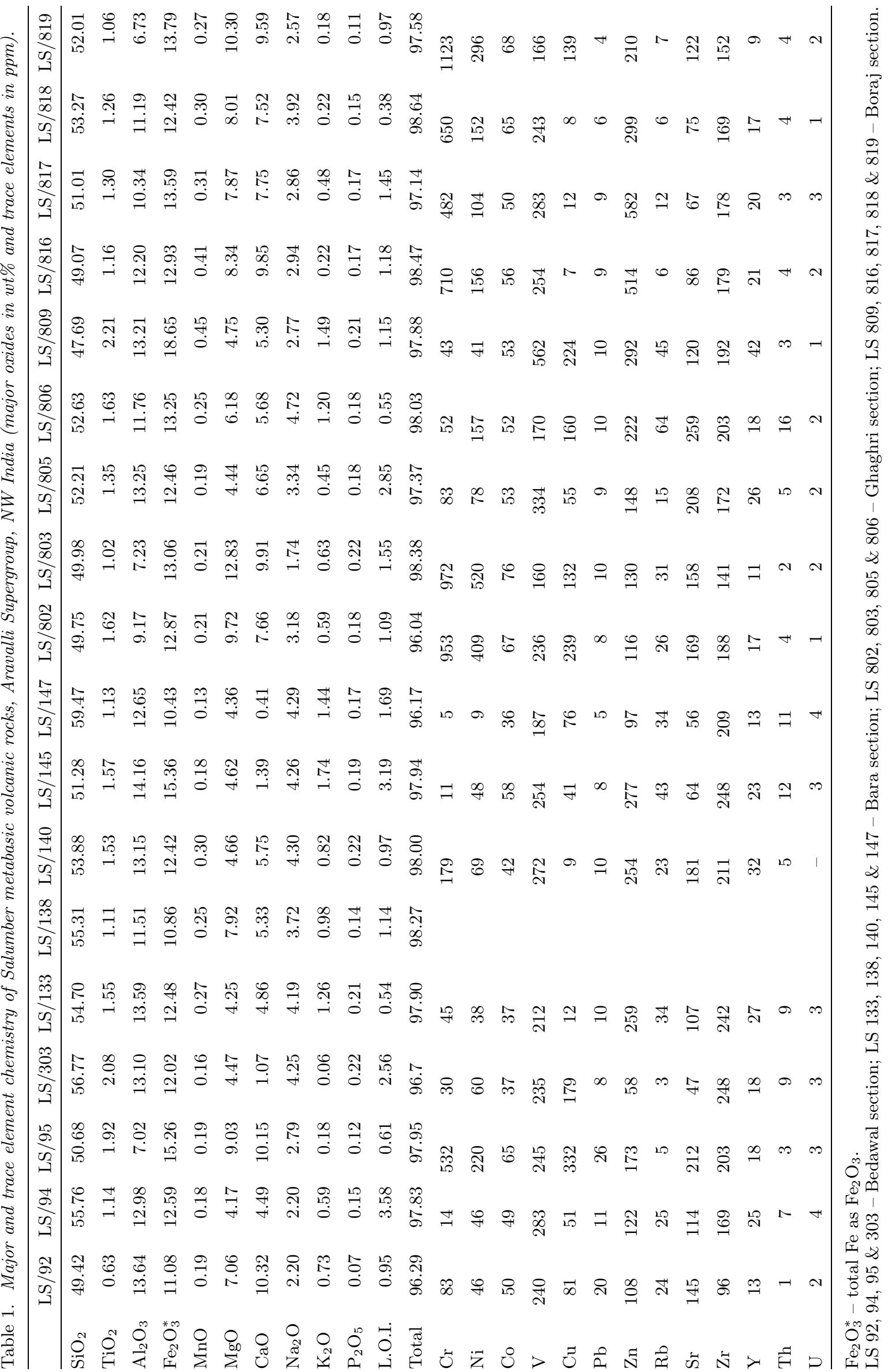


Table 2. REE analyses (in ppm) of Salumber metabasic volcanic rocks ( $L S / 94, L S / 803 /$ \& $L S / 817)$. Data on representative Aravalli metabasic volcanic rocks from other areas are also given for comparison.

\begin{tabular}{ccccccc}
\hline & LS/94 & LS/803 & LS/817 & TB & PB & JV \\
\hline $\mathrm{La}$ & 9.2 & 12.2 & 14.3 & 19.41 & 18.0 & 6.76 \\
$\mathrm{Ce}$ & 28.9 & 24.0 & 24.9 & 38.8 & 38.5 & 14.8 \\
$\mathrm{Nd}$ & 17.0 & 14.6 & 14.1 & 19.48 & 18.12 & 12.34 \\
$\mathrm{Sm}$ & 2.92 & 2.85 & 2.91 & 4.82 & 4.16 & 3.34 \\
$\mathrm{Eu}$ & 0.85 & 0.83 & 1.04 & 1.49 & 1.26 & 1.49 \\
$\mathrm{Gd}$ & 3.2 & 2.36 & 3.47 & 5.10 & 3.67 & 4.81 \\
$\mathrm{Dy}$ & 3.55 & 1.92 & 3.4 & 4.76 & 3.15 & 5.80 \\
$\mathrm{Er}$ & 1.78 & 0.99 & 1.95 & 2.69 & 1.59 & 3.42 \\
$\mathrm{Yb}$ & 1.63 & 0.88 & 1.65 & 2.29 & 1.25 & 3.37 \\
$\mathrm{Lu}$ & 0.16 & 0.09 & 0.22 & 0.32 & 0.17 & 0.46 \\
\hline $\mathrm{TB}$ & & & & & &
\end{tabular}

TB - Nathdwara tholeiitic basalt (average of 10 samples Ahmad and Tarney 1994); PB - Nathdwara picritic basalt (average of 12 samples - Ahmad and Tarney 1994) and JV - Jharol volcanics (average of 5 samples - Abu Hamatteh et al 1991).

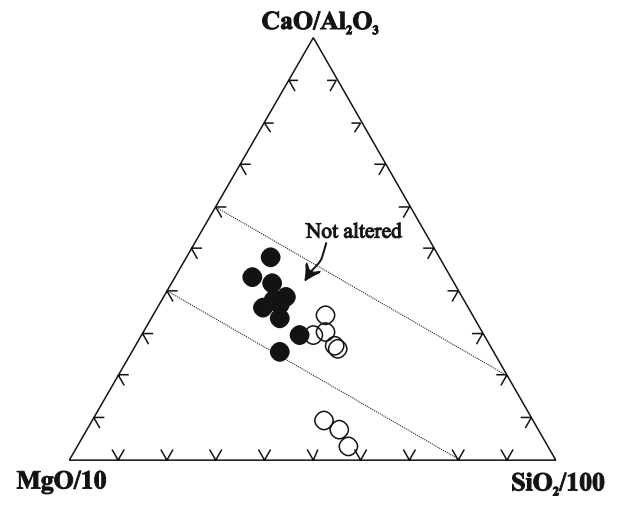

Figure 3. $\mathrm{CaO} / \mathrm{Al}_{2} \mathrm{O}_{3}-\mathrm{MgO}-\mathrm{SiO}_{2}$ diagram (Schweitzer and Kröner 1985) showing geochemically unaltered nature of most of the Salumber metabasic volcanic rock samples. Low $\mathrm{MgO}$ samples $(<5 \% \mathrm{MgO})$ are shown as open circles while rest $(>5 \% \mathrm{MgO})$ are shown as solid circles. Same symbols are used in subsequent diagrams.

close to the tholeiitic trend (figure 6). This diagram parallels many features of the AFM diagram with an advantage that it is based on immobile trace elements and likely to represent original igneous trends even when major elements may have been mobile.

Most of the major elements do not show perfect linear variations, which can be attributed to some degree of elemental mobility during metamorphism, a heterogeneous source and complex evolutionary history. There is a general positive correlation between $\mathrm{MgO}$ and $\mathrm{Cr}$ (figure $7 \mathrm{a})$, although in some of the low $\mathrm{MgO}(<5 \%)$ samples $\mathrm{Cr}$ abundances are not strictly correlative. Positive correlation between $\mathrm{MgO}$ and $\mathrm{Cr}$ can be attributed to simultaneous crystallization of

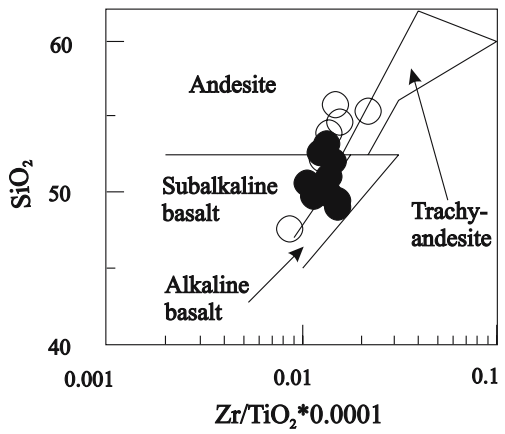

Figure 4. $\mathrm{Zr} / \mathrm{TiO}_{2}$ vs. $\mathrm{SiO}_{2}$ diagram (Winchester and Floyd 1977) showing subalkaline nature of Salumber metabasic volcanic rocks and their discrimination into basalt and andesite fields.

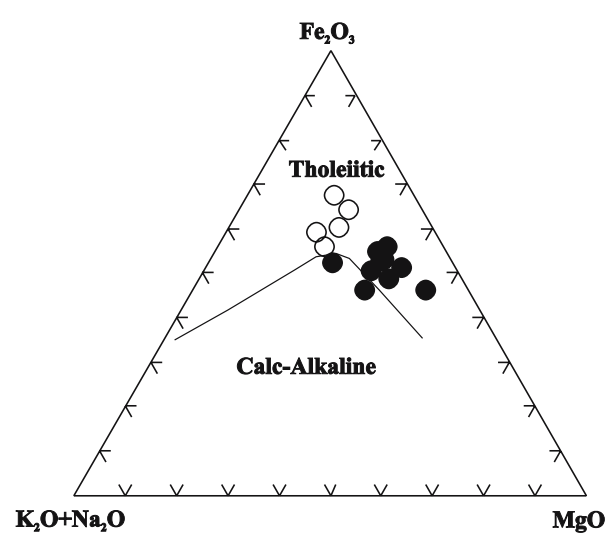

Figure 5. AFM diagram showing broadly tholeiitic character of Salumber volcanic rocks.

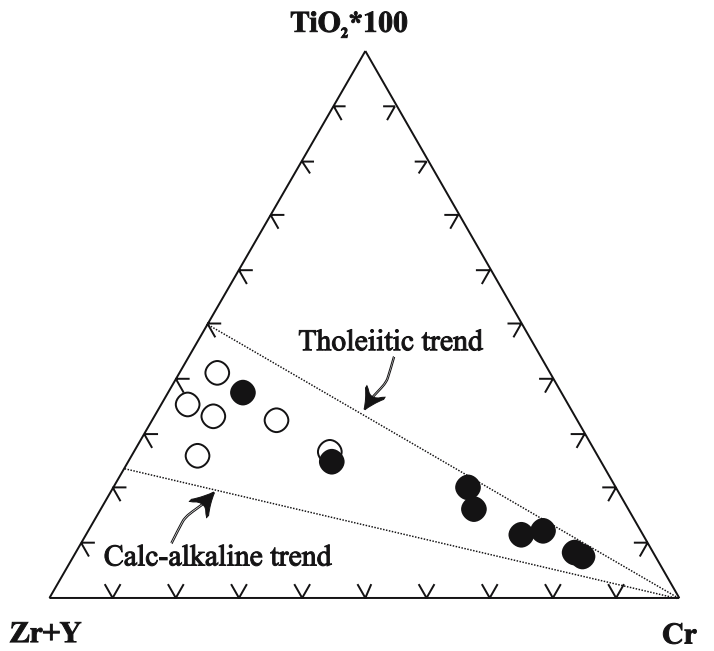

Figure 6. $\mathrm{Y}+\mathrm{Zr}-\mathrm{TiO}_{2}-\mathrm{Cr}$ diagram (Davies et al 1979) substantiating tholeiitic affinity of Salumber volcanic rocks.

olivine and pyroxene. Positive correlation between $\mathrm{CaO} / \mathrm{Al}_{2} \mathrm{O}_{3}$ and $\mathrm{MgO}$ also points out that olivine and pyroxene were the initial crystallizing phases (figure $7 \mathrm{~b}$ ). A broad positive correlation between $\mathrm{Fe}_{2} \mathrm{O}_{3} / \mathrm{MgO}$ and $\mathrm{Zr}$ also suggests the role of 
(a)

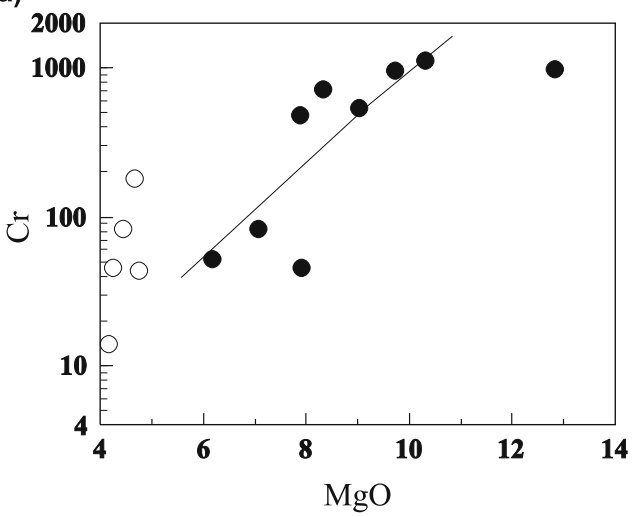

(c)

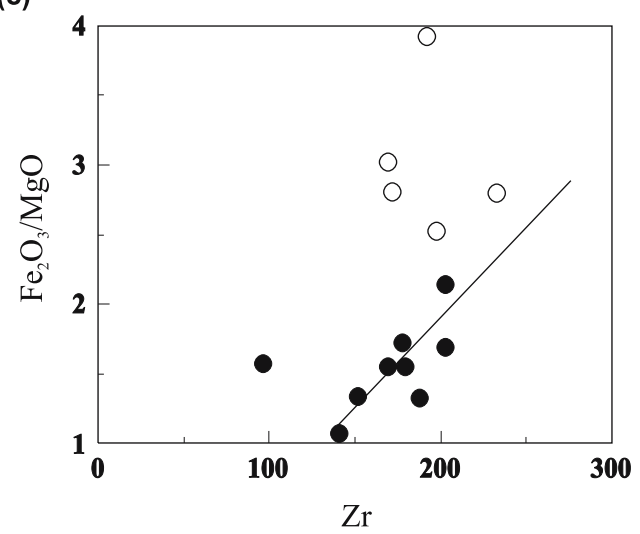

(b)

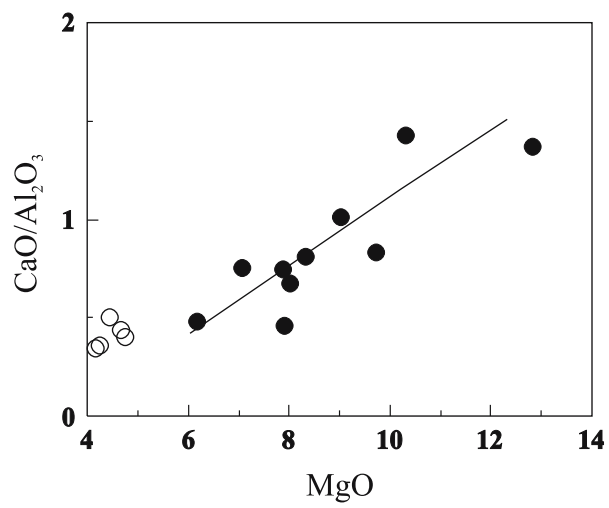

(d)

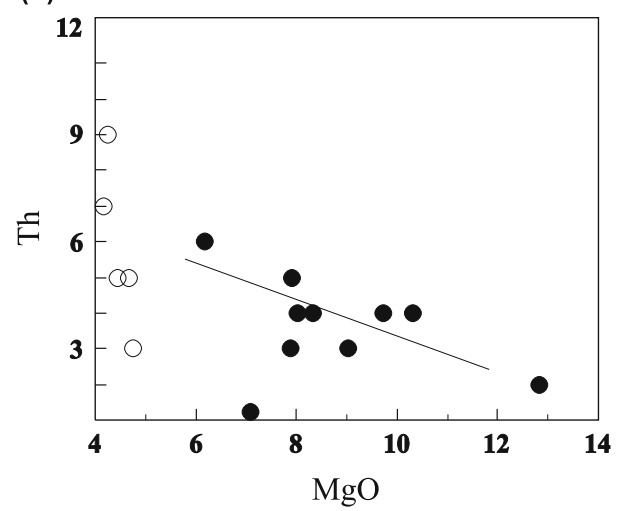

Figure 7. (a) $\mathrm{MgO}-\mathrm{Cr}$ diagram showing a general covariance between the two, more prominent in high $\mathrm{MgO}$ samples. (b) $\mathrm{MgO}-\mathrm{CaO} / \mathrm{Al}_{2} \mathrm{O}_{3}$ diagram showing a covariance. Note near constant of $\mathrm{CaO} / \mathrm{Al}_{2} \mathrm{O}_{3}$ ratio at lower $\mathrm{MgO}$ levels indicating onset of plagioclase separation at later stages of fractionation. (c) Covariance between $\mathrm{Fe}_{2} \mathrm{O}_{3} / \mathrm{MgO} \mathrm{ratio}$ and $\mathrm{Zr}$ (in ppm) abundance underlining the role of fractional crystallization. (d) $\mathrm{MgO}(\%)$ - Th (in ppm) diagram showing an inverse relationship between the two. Note lower Th abundances in some samples with low $\mathrm{MgO}$ contents.

fractional crystallization process; however, some low $\mathrm{MgO}$ samples plot away from the trend (figure $7 \mathrm{c}$ ). Inverse correlation between $\mathrm{Th}$ and $\mathrm{MgO}$ indicates fractional crystallization, barring some low $\mathrm{MgO}$ samples where Th abundances are much lower than expected (figure 7d). Such aberrations in trace element characteristics cannot be explained through simple fractional crystallization process and call for some other mechanism in addition to fractionation. A heterogeneous mantle source(s) and fractional crystallization of more than one phase would potentially result in such geochemical behaviour.

Although LREE are considered generally immobile (see for example, Jochum and Verma 1996, for sea-floor alteration), they can be somewhat mobile during sea-floor alteration (Ludden and Thompson 1979). Consistency of the chondrite normalized REE patterns in the present case suggests that the REE were not disturbed during alteration (consistent with Jochum and Verma 1996), deformation and metamorphism (figure 8). Chondrite normalized REE plots show LREE enriched
(25 to 40 times chondrite) patterns with a small negative $\mathrm{Eu}$ anomaly and $(\mathrm{Ce} / \mathrm{Yb})_{N}$ ratios ranging from 3.9 to 7.02 (figure 8). Insignificant $\mathrm{Eu}$ anomaly can be attributed to the fact that plagioclase fractionation was insignificant. Average REE values for Nathdwara tholeiitic and picritic basalts (Ahmad and Tarney 1994) and Jharol volcanics (Abu Hamatteh et al 1994) have also been plotted for comparison. The data for these groups are mathematical averages and have not been tested for normality and possible outliers (see Verma and Quiroz-Ruiz 2006, for details). If partial melting is fairly extensive $(>10 \%)$ the REE should not be fractionated from each other during melting and therefore the elemental ratios of critical REE (La/Sm, $\mathrm{La} / \mathrm{Yb}, \mathrm{Ce} / \mathrm{Yb}$ and $\mathrm{La} / \mathrm{Ce}$ ) should reflect the ratios in the mantle source (e.g., Rollinson 1993). However, only light REE are truly incompatible and thus only $\mathrm{La} / \mathrm{Ce}$ ratio is likely to be diagnostic of the source composition (Wilson 1989; Torres-Alvarado et al 2003). The LREE enriched patterns of Salumber volcanic rocks are comparable with the coeval picritic and 


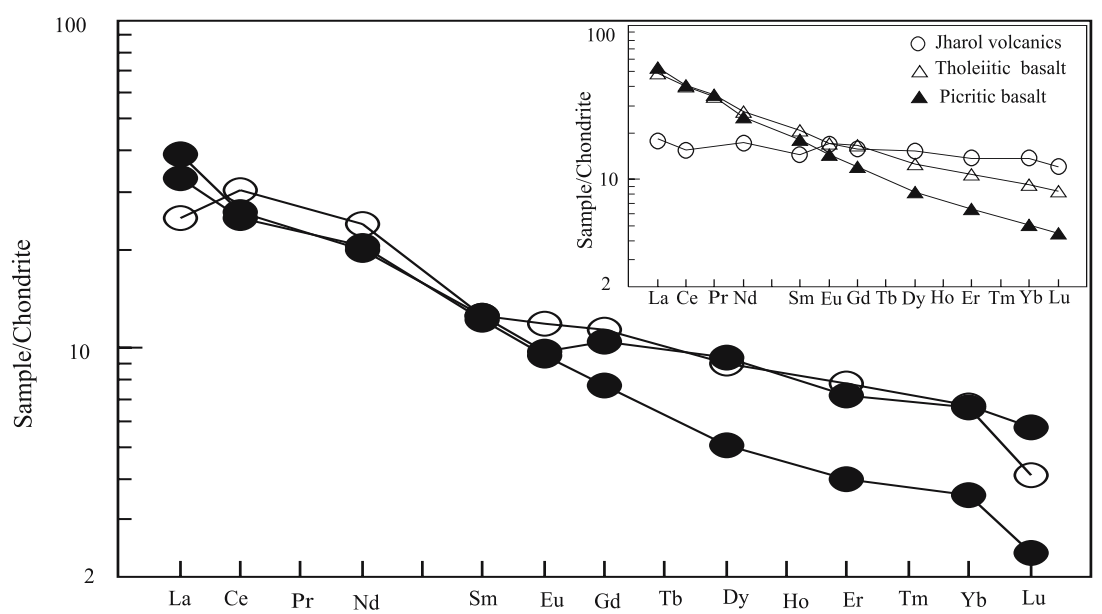

Figure 8. Chondrite normalized plots of Salumber volcanic rocks showing significantly LREE enriched patterns. The REE trends for Nathadwara komatiitic and tholeiitic basalts (Ahmad and Rajamani 1991) and Jharol volcanic rocks (Abu Hamatteh et al 1994) have also been provided in the inset, for comparison. Normalizing values after Sun and McDonnough (1989).

thoeliitic basalts of Nathdwara area and clearly distinct from the Jharol volcanic rocks, the latter a younger stratigraphic horizon in the Aravalli sequence and therefore a different magmatic event. The possibility of crustal contamination to account for the LREE enrichment in Salumber volcanic rocks seems unlikely on account of high Ni content in some low $\mathrm{MgO}$ samples, further supported by a lack of negative correlation between $\mathrm{Sr}$ and K. Therefore, mafic granulites seem the most likely contaminant. Assimilation of mafic granulites by the high-temperature basaltic melts can yield such high $\mathrm{Ni}$ values. The LREE enrichment is therefore a source characteristic, also seen in Nathdwara volcanic rocks (Ahmad and Rajamani 1991).

\subsection{Palaeotectonic discrimination}

A comparison of geochemical data with the modern lavas from known tectonic settings can be used to infer the tectonic setting of the metabasic volcanic rocks of the area. We have plotted our data in the recently proposed discrimination scheme for basic and ultrabasic rocks (Verma et al 2006). Although some of our samples have silica content slightly higher than the prescribed limit of $52 \%$ (adjusted), the samples appear to be consistent as the discrimination scheme utilizes multivariate major element data as $\log$ ratios. Total iron (reported as $\mathrm{Fe}_{2} \mathrm{O}_{3}$ in the present case) was readjusted along with other parameters using SINCLAS computer program and $100 \%$ adjustment (table 3 ) on an anhydrous basis (for details see Verma et al 2002). Our samples plot mainly in the MORB field in these diagrams (figure $9 \mathrm{~A}-\mathrm{D}$ ).

The tectonic discrimination diagrams based on the immobile and transitional elements (Ti, Zr, Y,
$\mathrm{V}, \mathrm{Cr}$ ) have been shown in figure 10. In the $\mathrm{V}-\mathrm{Ti}$ / 1000 discrimination diagram of Sheravis (1982), most of the Salumber samples plot in the combined MORB and BAB field with a few straddling the boundary with Arc Tholeiites (figure 10a). On the $\mathrm{TiO}_{2}-\mathrm{Zr}$ discrimination diagram of Pearce (1984) the samples plot as a cluster and show affinity with MORB lavas (figure 10b). In the $\mathrm{Ti}-\mathrm{Zr}-\mathrm{Y}$ triangular diagram (figure 10c) most of the samples plot in or close to the field of within plate basalts with some overlap with calc-alkaline types. The discrimination diagrams, therefore, suggest variable source characteristics. The Primordial Mantle normalized trace element multi-element diagrams for Salumber volcanic rocks show typical low-Ti tholeiite pattern and relative enrichment in incompatible elements such as $\mathrm{Zr}$ and $\mathrm{Th}$ (figure 11). The geochemical trends indicate that most of the metabasic volcanic rocks are unlikely to represent partial melts in equilibrium with mantle compositions. The trace element signatures also underline the effects of variable degrees of melting of an enriched source or variable source compositions. A 'continental' signature is reflected by a decoupling between LIL and HFS elements, i.e., negative $\mathrm{Sr}, \mathrm{Ti}$ and $\mathrm{P}$ anomalies (figure 11).

\section{Discussion}

Some of the Salumber volcanic rocks show geochemical characteristics of komatiitic basalt. A majority of komatiites reported world-wide have depleted LREE (see Sun and Nesbit 1978) although LREE enriched komatiites have also been reported (Cattel 1987). All the Salumber volcanic rock samples analyzed in this study (irrespective 
Table 3. Readjusted major element data (following the scheme of Verma et al 2002) used in tectonic discrimination diagram (Verma et al 2006) given in figure $9($ a) to $9(d)$.

\begin{tabular}{|c|c|c|c|c|c|c|c|c|}
\hline \multirow[b]{2}{*}{ Sample ID } & \multicolumn{2}{|c|}{ Figure $9(\mathrm{a})$} & \multicolumn{2}{|c|}{ Figure $9(\mathrm{~b})$} & \multicolumn{2}{|c|}{ Figure $9(\mathrm{c})$} & \multicolumn{2}{|c|}{ Figure $9(\mathrm{~d})$} \\
\hline & DF1 & DF2 & DF1 & DF2 & DF1 & DF2 & DF1 & DF2 \\
\hline $\mathrm{LS} / 92$ & -3.7452 & -1.1893 & 0.9603 & -4.0052 & -4.4141 & 0.7375 & -0.1548 & -2.8461 \\
\hline LS/95 & 3.3615 & -3.2367 & -4.7737 & 1.4043 & 2.4323 & -2.9323 & -3.7045 & 1.4890 \\
\hline LS/802 & 1.2153 & -1.0424 & -1.4484 & 0.6849 & 0.1090 & -0.7873 & -1.1210 & -0.2076 \\
\hline LS/803 & -0.7405 & -0.6093 & -1.3248 & -1.3876 & -2.1393 & -1.5269 & 0.2569 & -3.4178 \\
\hline $\mathrm{LS} / 05$ & -0.1135 & -0.5455 & -0.5387 & -0.5948 & -1.8405 & -0.5020 & -0.5975 & -1.6212 \\
\hline LS/806 & 0.0119 & 0.1313 & 0.3287 & -0.0140 & -1.8265 & -0.0877 & -0.1925 & -1.5299 \\
\hline LS/809 & -1.7273 & -0.9066 & 3.3790 & -1.2596 & -2.7647 & 3.6573 & 2.0952 & -0.2227 \\
\hline LS/816 & -1.2588 & -2.2099 & -1.0937 & -2.1364 & -1.6328 & -1.2178 & -1.6107 & -1.7147 \\
\hline $\mathrm{LS} / 17$ & -0.4168 & -1.7607 & -0.7963 & -1.1336 & -1.3574 & -0.1713 & -0.7969 & -0.9248 \\
\hline LS/818 & 0.5036 & -1.4313 & -2.2056 & -0.5199 & -0.8631 & -2.1890 & -2.1375 & -1.5002 \\
\hline LS/819 & 0.9103 & -3.4813 & -4.5356 & -1.2702 & -0.2282 & -3.4901 & -3.8462 & -0.6886 \\
\hline
\end{tabular}
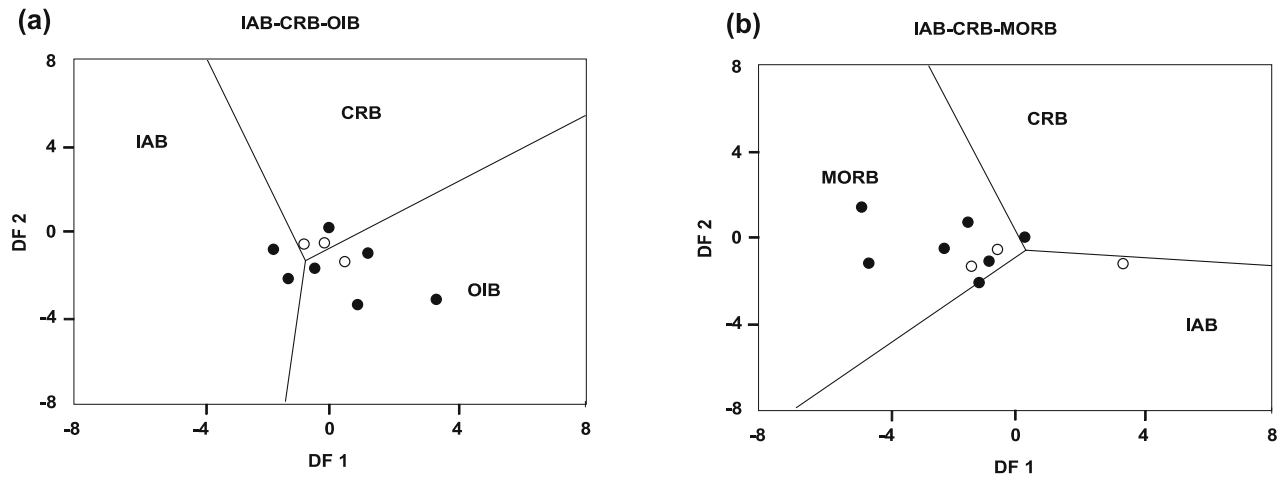

(c)



Figure 9. Palaeotectonic discrimination (Verma et al 2006) for metabasic volcanic rocks of Salumber area showing a general MORB affinity. Eleven rock samples with $\left(\mathrm{SiO}_{2}\right)_{\mathrm{Adj}}<56 \%$ were plotted on these diagrams. (a) IAB-CRB-OIB-MORB; (b) IAB-CRB-MORB; (c) IAB-OIB-MORB and (d) CRB-OIB-MORB.

of their $\mathrm{MgO}$ contents) are LREE enriched and therefore it may be appropriate to call them as high $\mathrm{Mg}$ tholeiites and tholeiites. In addition to LREE enrichment, the samples are also enriched in other incompatible elements, similar to continental tholeiites or P-type MORB. $\mathrm{Al}_{2} \mathrm{O}_{3}, \mathrm{TiO}_{2}$ and $\mathrm{CaO}$ relationships can be used to evaluate petrogenetic features. In Salumber volcanic rocks, $\mathrm{Al}_{2} \mathrm{O}_{3}$ does not show much variation as compared to $\mathrm{TiO}_{2}$ and
$\mathrm{CaO}$. If we assume that the variation in $\mathrm{CaO}$ is an original attribute of the magma, it is likely that $\mathrm{Al}_{2} \mathrm{O}_{3}$ was most likely controlled by residual phases (garnet, spinel) during partial melting. A large variation both in $\mathrm{CaO} / \mathrm{Al}_{2} \mathrm{O}_{3}$ ratio and in $\mathrm{TiO}_{2}$ content cannot be related to a single source and a simple fractionation process involving olivine \pm clinopyroxene \pm plagioclase. These inferences are in agreement with observations made by Ahmad 
(a)

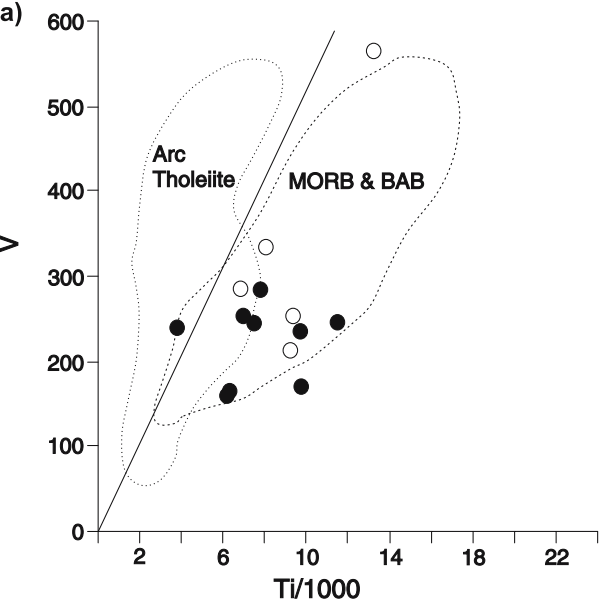

(b)

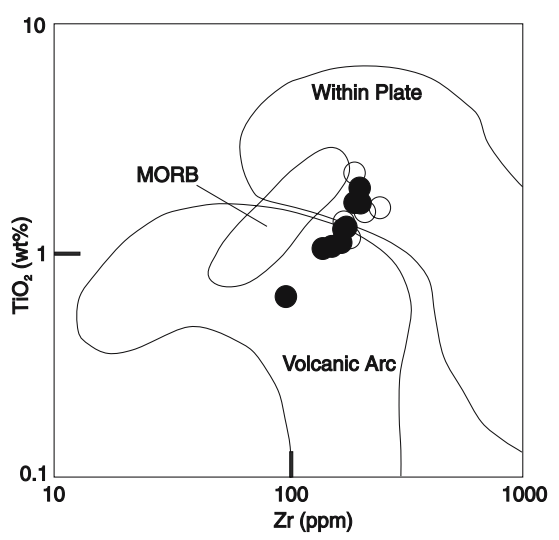

(c)

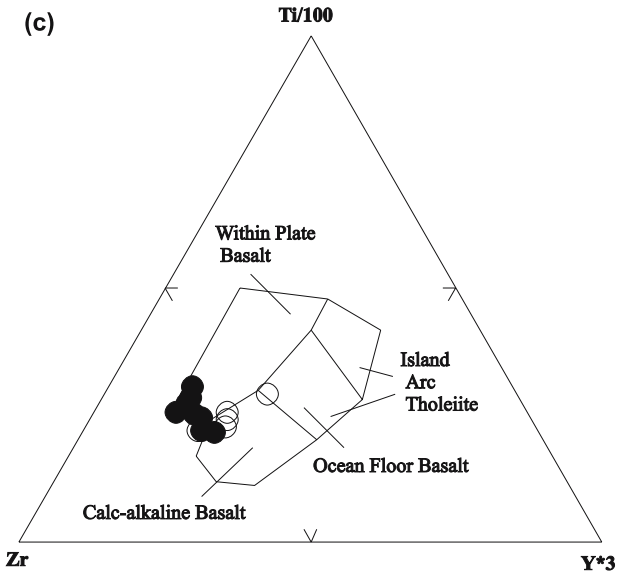

Figure 10. Tectonic discrimination diagrams for metabasic volcanic rocks of Salumber area. (a) Ti versus $\mathrm{V}$ diagram (Sheravis 1982) showing Mid Ocean Ridge Basalt (MORB) and Back Arc Basin (BAB) affinity with a slight overlap with Arc Tholeiites. (b) $\mathrm{TiO}_{2}(\%)$ versus $\mathrm{Zr}$ (ppm) diagram (Pearce 1984) showing MORB affinity. (c) $\mathrm{Zr}-\mathrm{Ti}-\mathrm{Y}$ diagram (Pearce and Cann 1973) showing predominant Within Plate basalt character.

and Rajamani (1991) for geochemically similar and coeval Nathdwara metabasic volcanic rocks.

The immobile trace element discrimination patterns suggest Within Plate setting. However, some samples show MORB affinity which is consistent with the reported MORB like source for Proterozoic rift related basalts in the Indian shield (Raza and Khan 1993). In the present case, a small Eu anomaly in one sample (LS/94) appears more likely related to minor plagioclase in the liquidus phase because the rocks seem to have preserved much of their primary chemistry as indicated by immobile elements and REE patterns. Considering the geochemical criteria diagnostic of pristine magma, none of the rocks are likely to represent partial melts in equilibrium with mantle mineralogy. These are evolved rocks that have undergone significant fractional crystallization.

Most of the tectonic discrimination diagrams show features overlapping with different tectonic settings. This can be explained either by the transitional nature between such settings or involvement of lithosphere in magma generation. Since field evidence suggests a rift setting for Salumber volcanic rocks, involvement of lithosphere in magma generation seems a more likely proposition. A continuum of trends in some major and trace elements and consistency in the REE patterns observed in Salumber volcanic rocks underline a relationship between komatiitic basalts and tholeiites through fractional crystallization. However, the complexities indicated by the more evolved lavas need to be explained. Some samples have higher silica content than expected for a given level of $\mathrm{MgO}$. This can be attributed to 'crustal contamination' but their lower $\mathrm{Al}_{2} \mathrm{O}_{3}$ and higher $\mathrm{Fe}_{2} \mathrm{O}_{3}$ (and other trace element characteristics) contents are not consistent with crustal contamination. The "continental' signature in the magma can be attributed to a lithospheric component. We interpret the alkaline affinity and REE enrichment in Salumber volcanic rocks to indicate an enriched shallow lithospheric source (Bailey 1983). Some elemental relationships are consistent with a predominant olivinepyroxene fractionation. Raza and Khan (1993) have postulated a unique tectonothermal setting for the basal Aravalli metabasic volcanic rocks on the basis of geochemical features transitional between Archaean greenstone belts and Phanerozoic suites. The LREE enriched nature of these rocks (see also Ahmad and Rajamani 1991) indicates variable melting of LREE enriched sources.

\subsection{A possible aulacogen setting?}

The regional NNE trend of Aravalli basin margin changes to nearly E-W in Salumber area, NNW-SSE in Anjeni-Ghaghri area and NW-SE in Ghaghri-Bedawal area (figure 1,2). Such trends of the Aravalli basin margin are considered to be original and not acquired during later deformation (Naha and Mohanty 1988; Sinha Roy et al 1998). Roy (1988) has also opined that the basement in 


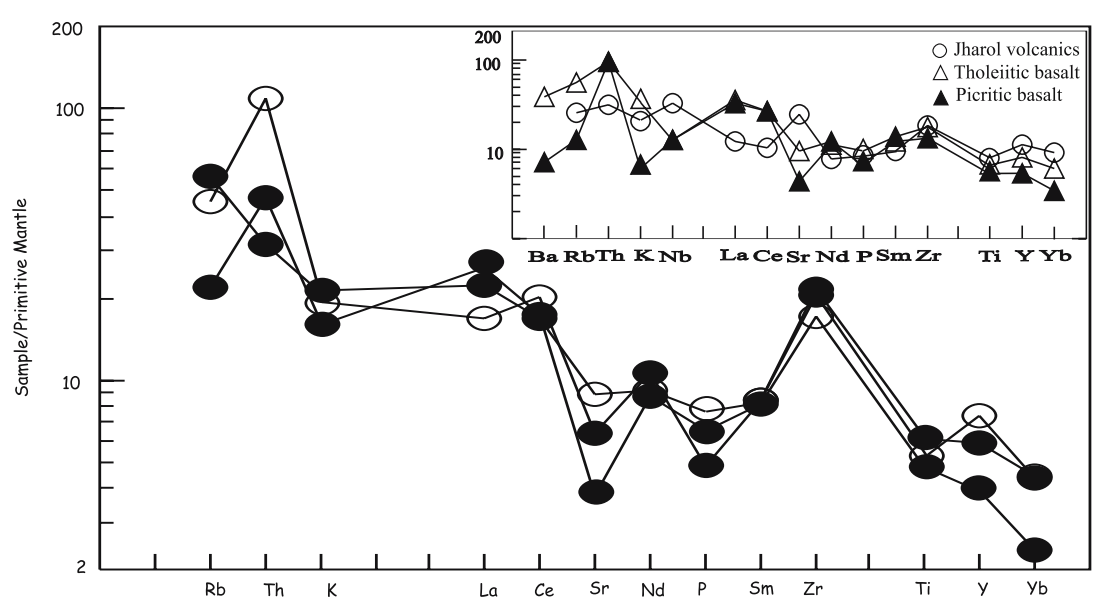

Figure 11. Primordial Mantle (PM) normalized multi-element diagrams for Salumber volcanic rocks showing relative enrichment in incompatible elements (Th, Zr) and similarity with low-Ti basalts. Aravalli metabasic volcanic rocks from Nathdwara area (picritic and tholeiitic basalts) and Jharol volcanic rocks have also been plotted for comparison. Normalizing values after Sun and McDonnough (1989); the Nathdwara and Jharol data are from Ahmad and Rajamani (1991) and Abu Hamatteh et al (1994), respectively.

Anjeni area (figure 2) was not folded during deformation of the Aravalli sequence. In view of the above, trends of basin margin in Salumber area may represent three arms of a rift system with triple junction near Ghaghri. Furthermore, the NNW-SSE trending arm (Northern Arm), developed in Anjeni-Ghaghri area, is represented by a narrow basin and a limited number of lithounits of Aravalli Supergroup, compared to the E-W and NW-SE trending arms that host more lithounits. The northern arm has a synclinal structure with steep axial plane. The development of a limited number of lithounits and presence of basement rocks on its either side (figure 2) implicate the narrow Northern Arm to be a failed one (aulacogen) which could not open further while the other two arms continued to open. However, it can be argued that the region is not large enough to qualify for a plate triple junction. The possibility that it might be representing a remnant un-eroded part of a much larger structure needs consideration and further evaluation. The possible aulacogen setting is also supported by observations of Ahmad and Rajamani (1991), who ascribed Aravalli volcanism to the rise of a mantle plume. Physical conditions and source characteristics of tholeiites indicate that their magmas were generated within the lithosphere, perhaps by emplacement of high pressure picritic or komatiitic melts. The Aravalli basin itself could have formed because of lithospheric thinning associated with plume activity (Ahmad and Rajamani 1991). It is widely accepted (see Vink et al 1985) that plume activity can result in formation of a triple junction. The question whether it represents a true aulacogen should therefore await further substantiation through detailed studies on structural geometry, depositional history and regional tectonics.

\section{Conclusion}

The basal Aravalli metabasic volcanic rocks of Salumber area were extruded in a rift environment. Stratigraphically significant volcaniclastic/ conglomerate unit marks an unconformity between the Salumber volcanics and Malpura Formation. The metabasic volcanic rocks show iron enrichment and $\mathrm{Mg}$ - and Fe-tholeiitic nature. Geochemical characteristics of Salumber volcanic rocks underline a dominant fractional crystallization process in evolution of these metabasic volcanic rocks, which is also supported by a change in colour from dark greenish to light greenish upward in the volcanic sequence. Geochemical attributes, however, point towards a complex evolutionary history and diverse source characteristics. In the geotectonic discrimination schemes, these metabasic volcanic rocks show transitional source characteristics, mainly between Within Plate and MORB. The continental signatures, as indicated by some trace element relationships can be explained by invoking an enriched source, possibly an old subcontinental lithosphere rather than the asthenospheric MORBsource. Diverse trace element concentrations and other geochemical signatures point towards more than one mantle source. This inference needs to be evaluated and substantiated through additional trace element and isotopic data that would also offer constraints to ascertain and quantify the process and in establishing any compositional heterogeneity in the mantle itself. 


\section{Acknowledgements}

We are thankful to Dr. V P Misra, Mr. V K Kanchan, Mr. C P Sisodia and Dr. P R Golani of GSI for fruitful discussions. We are grateful to Dr. S P Verma for the formal review, comments and suggestions that improved the manuscript immensely. We sincerely thank two anonymous reviewers for their comments on an earlier version of the manuscript.

\section{References}

Abu-Hamatteh Z S H, Raza M and Ahmad T 1994 Geochemistry of early Proterozoic mafic and ultramafic rocks of Jharol Group, Rajasthan, Northwestern India; J. Geol. Soc. India 44 141-156.

Ahmad T and Rajamani V 1991 Geochemistry and petrogenesis of the basal Aravalli volcanics near Nathdwara, Rajasthan, India; Precamb. Res. 49 185-204.

Ahmad T and Tarney J 1994 Geochemistry and petrogenesis of Late Archaean Aravalli volcanics, basement enclaves and granitoids, Rajasthan; Precamb. Res. 65 1-23.

Bailey D K 1983 Chemical and thermal evolution of rifts; Tectonophys. 94 585-597.

Banerjee D M 1971 Aravalli stromatolites from Udaipur, Rajasthan, India; J. Geol. Soc. India 12 349-355.

Bose U, Mathur A K, Sahoo K C, Bhattacharya S, Dutt K, Kumar V A, Sarkar S S, Choudhary S and Chaudhary I 1996 Event stratigraphy and physico-chemcial characters of Banded Gneissic Complex and associated supracrustals in the south Mewar plains of Rajasthan; J. Geol. Soc. India 47 325-338.

Camire G, La Fleche M R and Jenner G A 1995 Geochemistry of pre-Taconian mafic volcanism in Humber Zone of northern Appalachians, Quebec, Canada; Chem. Geol. 119 55-77.

Cattel A 1987 Enriched komatiitic basalts from Newton Township, Ontario: their genesis by crustal contamination of depleted komatiitic magama; Geol. Mag. 124 303-309.

Davies J F, Grant R W E and Whitehead R E S 1979 Immobile trace elements and Archaean volcanic stratigraphy in the Timmins mining area, Ontario; Can. J. Earth Sci. 16 305-311.

Emslee R F 1991 Granitoids of rapakivi granite-anorthosite and related associations; Precamb. Res 51 173-192.

Goel O P 1988 Petrogenesis of basal Aravalli metabasites, east of Udaipur, Rajasthan; In: Precambrian of the Aravalli Mountain, Rajasthan, India (ed.) Roy A B; Geol. Soc. India Memoir. 7 317-326.

Green D H 1971 Composition of basaltic magmas as indicators of conditions of origin: application to oceanic volcanism; Phil. Trans. Roy. Soc. London 268 707-725.

Gupta B C 1934 The Geology of Central Mewar; Geol. Surv. India Memoir. 65 107-169.

Gupta S N, Arora Y K, Mathur R K, Iqbaluddin, Prasad B, Sahai T N and Sharma S B 1997 The Precambrian geology of the Aravalli region, southern Rajasthan and northeastern Gujarat; Geol. Surv. India Memoir. 123 p 262.

Hawkesworth C J, Kempton P D, Rogers N W, Ellam R M and van Calsteren P W 1990 Continental mantle lithosphere, and shallow level enrichment process it the earth's mantle; Earth Planet. Sci. Lett. 96 256-268.
Heron A M 1953 Geology of Central Rajputana; Geol. Surv. India Memoir. 79 389pp.

Jensen L S 1976 A new cation plot for classifying subalkaline volcanic rocks; Ont. Div. Mines, Misc. Pap. 66 22pp.

Jochum K P and Verma S P 1996 Extremely high enrichment of $\mathrm{Sb}, \mathrm{Tl}$ and other trace elements in altered MORB; Chem. Geol. 130 289-299.

Ludden J N and Thompson G 1979 An evaluation of the behaviour of the rare earth elements during the weathering of sea-floor basalts; Earth Planet Sci. Lett. 43 $85-92$.

Luhr J F 1997 Extensional tectonics and the diverse primitive volcanic rocks in the western Mexican Volcanic Belt; Can. Mineral. 35 473-500.

Macdougall J D, Willis R, Lugmair G W, Roy A B and Gopalan K 1984 The Aravalli sequence of Rajasthan, India: A Precambrian continental margin; Workshop on the Early Earth: the interval from accretion to the older Archaean. Lunar Planet. Inst., Houston, Texas, 55-56.

Naha K and Mohanty S 1988 Response of basement and cover rocks to multiple deformations: a study from the Precambrian of Rajasthan, western India; Precamb. Res. 42 77-96.

Pearce J A 1984 A user's guide to basalt discrimination diagrams; In: Oceanic Basalts (ed.) J Tarney (Amsterdam: Shiva Publications) 230-240.

Pearce J A and Cann J R 1973 Tectonic setting of basic volcanic rocks determined using trace element analysis Earth Planet. Sci. Lett. 19 290-300.

Ray A, Bhattacharyya P K, Mukherjee A D and Roy A B 1988 Sulphide mineralization in a zone of basement cover interaction near Anjeni, Udaipur district, Rajasthan; In: Precambrian of the Aravalli Mountain, Rajasthan, India (ed.) Roy A B; Geol. Soc. India Memoir. 7 373-384.

Raza M and Khan M S 1993 Basal Aravalli volcanism: Evidence for an abortive attempt to form Proterozoic ensialic greenstone belt in northwestern part of the Indian shield; J. Geol. Soc. India 42 493-512.

Rollinson H R 1993 Using geochemical data: evaluation, presentation, interpretation. Longman Scientific Technical, Essex, 344

Roy A B 1988 Stratigraphic and tectonic framework of the Aravalli Mountain Range; In: Precambrian of the Aravalli Mountain, Rajasthan, India (ed.) Roy A B; Geol. Soc. India Memoir. 7 3-31.

Roy A B and Jakhar S R 2002 Geology of Rajasthan (Northwest India) - Precambrian to Recent; Scientific Publishers (India), Jodhpur, pp 421.

Roy A B, Paliwal B S, Shekhawat S S, Nagori D K, Golani P R and Bejarniya B R 1988 Stratigraphy of the Aravalli Supergroup in the type area; In: Precambrian of the Aravalli Mountain, Rajasthan, India (ed.) Roy A B; Geol. Soc. India Memoir. 7 121-138.

Roy A B, Sharma B L, Paliwal B S, Chauhan N K, Nagori D K, Golani P R, Bejarniya B R, Bhu H and Ali S M 1993 Litho-stratigraphy and tectonic evolution of the Aravalli Supergroup - A Protogeosynclinal sequence; In: Rift Basins and Aulacogens (ed.) Cassyap S M, Gyanodaya Prakashan, Nainital, 73-90.

Roy A B and Kröner A 1996 Single zircon evaporation ages constraining the growth of the Archean Aravalli craton, northwestern Indian shield; Geol. Mag. 133 333-342.

Roy A B and Paliwal B S 1981 Evolution of the Lower Proterozoic epicontinental deposits: stromatolites bearing Aravalli rocks of Udaipur, Rajasthan, India; Precamb. Res. 14 49-74.

Sarkar S N 1980 Precambrian stratigraphy and geochronology of Peninsular India, a review; Indian J. Earth Sci. 8 119-130. 
Sastry C A, Gopalan K and Choudhary A K 1984 Proposals for time classification of the Precambrian rocks and events from Rajasthan and NE Gujarat. Seminar on Crustal Evolution of the Indian Shield and its bearing on Metallogeny, Calcutta, 33 (abstr).

Sato H 1977 Nickel content of basaltic magmas: Identification of primary magmas and the measure of the degree of olivine fractionation; Lithos 10 113-120.

Schiano P, Dupre B and Lewin B 1993 Application of element concentration variability to the study of basalt alteration (Fanagataufa Atoll, French Polynesia); Chem. Geol. 104 99-124.

Schweitzer J and Kröner A 1985 Geochemistry and petrogenesis of early Proterozoic intracratonic volcanic rocks of the Ventersdrop Supergroup, South Africa; Chem. Geol. $51265-288$

Sengupta S 1976 Structures and stratigraphic relations in the Aravallis, southeastern Rajasthan; J. Geol. Soc. India 17 461-470.

Sharma R S 1988 Patterns of metamorphism in the Precambrian rocks of the Aravalli Mountain belt; In: Precambrian of the Aravalli Mountain, Rajasthan, India (ed) Roy A B; Geol. Soc. India Memoir 7 33-75.

Shekhawat L S 1998 Geology of the Aravalli fold belt of the Jaisamand - Salumber area, south Rajasthan; Ph.D. thesis, University of Rajashan, Jaipur, pp 116.

Shekhawat L S, Joshi D W and Pandit M K 2000 Stratigraphic status of the conglomerate occurring north and northwest of Salumber in western Indian craton: Implications on geology of Palaeoproterozoic Aravalli Supergroup; Gondwana Res. 3 245-249.

Shekhawat L S, Joshi D W and Pandit M K 2001 A relook into the status of granitoids and conglomerate in Salumber - Jaisamand area, southern Rajasthan: Implications for the stratigraphy of the Palaeoproterozoic Aravalli Fold Belt; J. Geol. Soc. India 58 53-63.

Sheravis J W $1982 \mathrm{Ti}-\mathrm{V}$ plots and petrogenesis of modern and ophiolitic basaltic lavas; Earth Planet. Sci. Lett. 59 101-118.

Sinha Roy S 1988 Proterozoic Wilson Cycles in Rajasthan; Geol. Soc. India Memoir. 7 95-107.

Sinha Roy S, Malhotra G and Mohanty M 1998 Geology of Rajasthan. Geol. Soc. India, Bangalore, pp 278.

Sun S-s and McDonnough W F 1989 Chemical and isotopic systematics of ocean basalts: implications for mantle composition and processes; In: Magmatism in the Ocean Basins (eds) Saunders A D and Norry M J; Geol. Soc. London, Spec. Publ. 42 313-345.
Sun S-s, and Nesbitt R W 1978 Petrogenesis of Archaean ultrabasic and basic volcanics: Evidence from rare earth elements; Contrib. Mineral. Petrol. 65 301-325.

Sweeny R J, Duncan A R and Erlank A J 1994 Geochemistry and petrogenesis of central Lebombo basalts of the Karoo Igneous Province; J. Petrol. 35 95-125.

Swinden H S, Jenner G A, Fryer B J, Hertogen J and Roddick J C 1990 Petrogenesis and palaeotectonic history of the Wild Bight Group, an Ordovician rifted island arc in central New Foundland; Contrib. Mineral. Petrol. $105219-241$.

Tatsumi Y, Sakuyama M, Fukuyama H and Kushiro I 1983 Generation of arc basalt magmas and the thermal structure of the mantle wedge in subduction zone; J. Geophys. Res. 88 5815-5825.

Torres-Alvarado I S, Verma S P, Palacios-Berruete $\mathrm{H}$, Guevara M and González-Castillo O Y 2003 DC_Base: a database system to manage Nernst distribution coefficients and its application to partial melting modeling; Compu. Geosci. 29 1191-1198.

Verma S P 2003 Geochemical and Sr-Nd isotopic evidence for a rift-related origin of Magmas in Tizayuca Volcanic field, central Mexican Volcanic belt; J. Geol. Soc. India $61257-276$.

Verma S P, Guevara M and Agrawal S 2006 Discriminating four tectonic settings: Five new geochemical diagrams for basic and ultrabasic volcanic rocks on log-ratio transformation of major element data; J. Earth Syst. Sci. 115 485-528.

Verma S P, Torres-Alvarado I S and Sotelo-Rodríguez Z T 2002 SINCLAS: standard igneous norm and volcanic rock classification system; Comput. Geosci. 28 711-715.

Verma S P and Quiroz-Ruiz A 2006 Critical values for six Dixon tests for outliers in normal samples up to sizes 100, and applications in science and engineering; Revista Mexicana de Ciencias Geológicas 23 133-161.

Vink G E, Morgan W J and Vogt P R 1985 The Earth's Hotspots; Scientific Amer. 252 50-56.

Wilson M 1989 Igneous Petrogenesis (London: Unwin Hyman) pp 466.

Winchester J A and Floyd P A 1977 Geochemical discrimination of different magma series and their differentiation products using immombile elements; Chem. Geol. 20 325-343.

Windley B F 1999 The Evolving Continents (New York: John Wiley) pp 526. 